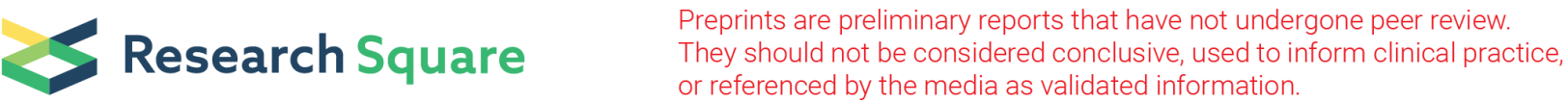

\section{High prevalence of under-five child mortality in the pastoralist communities of Ethiopia: Evidence from the 2016 Ethiopian demographic and health survey data}

Mesfin Wudu Kassaw ( $\nabla$ mesfine12a@gmail.com )

Woldia University https://orcid.org/0000-0002-6327-7723

Aele Mamo

Debre Berhan University

Biruk Abate

Woldia University

Ayelign Kassie

Woldia University

Seteamlak Masresha

Woldia University

Research article

Keywords: Under-five mortality, Pastoralist communities, Ethiopia, EDHS

Posted Date: August 21st, 2020

DOI: https://doi.org/10.21203/rs.3.rs-61694/v1

License: (c) (i) This work is licensed under a Creative Commons Attribution 4.0 International License. Read Full License 


\section{Abstract}

Objective: The aim of this study was to assess the prevalence and association of child mortality in the pastoralist regions of Ethiopia. The study is a further analysis from 2016 Ethiopian Demographic and Health Survey data.

Results: The prevalence of under-five child mortality in the pastoralist's regions was $23.2 \%, 95 \% \mathrm{Cl}(21.4 \%$, $24.6 \%)$. The prevalence of mortality among daughters was $15.4 \%, 95 \% \mathrm{Cl}(14.2,16.6 \%)$, and sons $16.8 \%$, $95 \% \mathrm{Cl}(15.6,18.1 \%)$.In logistic regression, wealth index, head of household, Khat chewing, type of child birth, husband education, and child age in months were associated with under-five mortality irrespective of the deceased children's gender. The prevalence of under-five child mortality in the pastoralist regions of Ethiopia was high, which was far highest in relative to the national under-five mortality prevalence. In assessing the effect of variables on under-five child mortality by gender, almost all the variables that have an effect on female or male child are similar. The government should emphasize on the pastoralists' regions to decrease the high prevalence of under-five child mortality.

\section{Introduction}

Worldwide, nearly 15,000 children die daily from preventable and treatable diseases such as diarrhea, malaria and fever(1). However, the world has made substantial progress in reducing child mortality over the last four decades (2-4). Despite such global progress in reducing child mortality over the past decades, an estimated 5.4 million children under the age of five years were died in 2017, and half of those deaths occurred in subSaharan Africa(5). Under-five mortality is a leading indicator of child health and overall development of a nation, since it reflects the social, economic, and environmental conditions in which children live(6). SubSaharan Africa countries continue to confront significant challenges of the highest child mortality rates in the world. In this risky region, 98 deaths per 1,000 live births were recorded in 2012. Sixteen countries that had under-five mortality rate above 100 deaths per 1,000 live births werealso in sub-Saharan Africa(7).The 2015 UN Inter-Agency Group for Child Mortality Estimation (IGME) report, Ethiopia reached its target for Millennium Development Goal 4 for child survival with an estimated under-five mortality rate of 59 per 1000 live births in 2015. This represents an average reduction in mortality of $5 \%$ per year which was higher than the average for sub-Saharan Africa (2.9\%)(8). However the pastoralist regions had a highest prevalence of under-five mortality. For example the child mortality rates in Afar region were very high. In this region, both under-five mortality rate and infant mortality rate were the highest in Ethiopia. It is worrying that during the past ten years no progress has been made to reduce early childhood deaths in this region. However childhood mortality rates are decreasing in Ethiopia, but in Afar region the rates are still increasing(9). The reason for such persistent child mortality in Afar region might be as a result of highest deprivation rate in health $(80 \%)$ and nutrition (85\%) compared to the other regions(10). The other three regions were also grouped in thetop fourregions in having thehighest rates of child mortality including Afar region. According to the 2011 Ethiopia Demographic and Health Survey data, under-five mortality rates per 1000 live births in Benishangul-Gumuz was 169, in Afar was 127, in Gambelawas 122, and in Somalia123(11). However, the sustainable development goal's target is to reduce under-five mortality rate to below 25 under-five deaths per 
1000 live births at the end of 2030(12). The aim of this study wasto assess the prevalence and association of under-five child mortality in the pastoralist regions of Ethiopia.

\section{Methods}

\section{Data collection period, study design, and data collection}

The data collection period for the 2016 EDHS was from January 18 to June 27, 2016. The 2016 Ethiopian Demographic and Health Survey (EDHS) data was used for this further analysis. The 2016 EDHS data was the fourth survey conducted in Ethiopia. The survey collected information on household's and respondent's characteristics, child health, infant and child mortality, malaria, maternal health, maternal mortality, nutrition, tobacco use, women's empowerment, anemia, domestic violence, environmental health, family planning, fertility and fertility preferences, and etc. The purpose of the EDHS is to provide up-to-date estimates of the key demographic and health indicators of the population (13). The survey included reproductive age group women, under-five children, and productive age group men (aged 15-59 years) $(13,14)$

\section{Sampling technique and study population}

The 2016 EDHS data collected using a stratified two stage sampling method to select a representative sample. All the regions of the country were stratified into urban and rural areas. From the total 11 administrative states, 21 sampling strata were yielded. The samples of the enumeration areas (EAs) were selected independently in each stratum in two stages. The implicit stratification and proportional allocation were achieved at each of the lower administrative levels by sorting the sampling frame within each sampling stratum before sample selection according to the administrative units at different levels, and by using a probability proportion to size selection at the first stage of sampling. The 2016 EDHS data collected from 645 EAs with a probability proportional to the EA size and with independent selection in each sampling stratum. The EA size is the number of residential households in the EA that was determined in the 2007 Ethiopian Population and Housing Census. According to the 2016 EDHS procedures, a household listing operation was implemented in the selected EAs, and the resulting lists of households served as the sampling frame for the selection of households in the second stage. All the under-five children, who were usual members of the selected households or who spent the night before the survey in the selected households were eligible for the child survey (14). After managing the missing data, 3527 respondents that had under-five children were included for this frther analysis. However, the 2016 EDHS data collected data from $10641 \mathrm{children}$. But, the original EDHS data were undergoningthrough rigorous phases of data refining until we get the final sample size.

\section{Data collection tools and procedure}

The EDHS usually use five groups of questionnaires in collecting the data. Those questionnaires are the Household questionnaire, the woman's questionnaire, the man's questionnaire, the biomarker questionnaire, and the health facility questionnaire. The questionnaires were adapted from the DHS program's standard demographic and health survey questionnaires in a way to reflect the population and health issues relevant to Ethiopia. Questions that stated about children were integrated to woman's questionnaire. 


\section{Variables}

The outcome variable of this further analysis was under-five child mortality. The independent variableswere socio-demographic variables of both children and mothers, health services provided to children and the wider community, substance use such as maternal chat chewing and Cigarette smoking in considering the availability of the variables in the 2016 EDHS data.

\section{Definition}

Under-five child mortality: The report of mothers that they lost children in their life timebefore two weeks of the 2016 EDHS data collection takes placed

Under-five children: Children from birth to 59 completed months at June 27/2016

Pastoralist regions: Afar, Somalia, Benishangul, and Gambella regions were considered as pastoralist communities in this further analysis.

\section{Results}

\section{Socio-demographic characteristics}

In this study, 2385(67.6\%) husbands did not have professional works, but 1641(46.5\%) mothers involved in agricultural jobs. More than eighty five percent $3008(85.3 \%)$ of mothers were rural residents, $2711(76.9 \%)$ mothers were gave birth in home, and 3505(99.4\%) mothers were married. Regarding religion $2574(73.0 \%)$ mothers were a follower of Muslim, and 2593(73.5\%) were unable to read and write.

\section{Prevalence of under-five child mortality}

The number of children included to this study from Afar were 904(25.6\%), Somalia 1278(36.2\%), Benishangul-Gumz 771(21.9\%), and Gambella 574(16.3\%). The prevalence of under-five childmortality in these four pastoralist region was $23.2 \%, 95 \% \mathrm{Cl}(21.4 \%, 24.6 \%)$. However, the prevalence of mortality among daughters was $15.4 \%, 95 \% \mathrm{Cl}(14.2,16.6 \%)$, and sons was $16.8 \%, 95 \% \mathrm{Cl}(15.6,18.1 \%)$. The maximum numbers of death were 4 (Table2).

\section{Association of under-five child mortality}

In this study, the associations of under-five child mortality and potential determinates were measured in considering the gender of deceased children. This means, the factors of mortality for under-five female, and under-five male children were computed separately. In the final logistic regression model,wealth index, head of household, Khat chewing, type of child birth, husband education, and child age in months were associated with under-five child mortality in the pastoralist regions of Ethiopia regardless of the deceased children's gender (Table3). The association of under-five child mortality and potential factors were also assessed by gender. In the final logistic regression model, wealth index, religion, head of household, wontedness of the child, husband education, and short and rapid breathing were associated with under-five sons' mortality in the pastoralist regions of Ethiopia (Table4).In the final logistic regression model, wealth index, religion, head 
of household, type of child birth, child age in months, husband education, and size of child at birth were associated with under-five girls' mortality in the pastoralist regions of Ethiopia (Table5).

\section{Discussion}

The aim of this study was to assess the prevalence and association of under-five child mortality in the pastoralist communities of Ethiopia. The present study reported $23.2 \%, 95 \% \mathrm{Cl}(21.4 \%, 24.6 \%)$ of under-five child mortality in the pastoralist regions, Ethiopia. This current prevalence is similar with the global prevalence of under-five mortality 21.6\%(15), and the UN Inter-Agency Groupprevalence of under-five mortality for Latin America and the Caribbean regions, 27.0\% (16). The similarity might be as a result of comparable socioeconomic status between Ethiopia, and Latin America or the Caribbean regions. The present study's prevalence of under-five child mortality is also similar with a study that reported a $22.9 \%$ of under-five mortality from Afar region (17).The prevalence of the current study is higher than the prevalence of U5M in the west Africa countries that varied from the highest 11.1\%in Sierra Leone, Nigeria 10.0\%, Mali 10.6\%, to the smallest prevalence of mortality in Cape Verde 1.7\%(18). The difference might be as result of socio-economic difference. The former studies were a nationwide studies but the current study consider the poorest regions in Ethiopia that might contribute for the highest prevalence of under-five child mortality. The prevalence of under-five mortality in the pastoralist regions arehigher than the 2016 EDHS based studythat reported 6.7\% (5). The difference might be as a result of socio-demographic difference between the pastoralist regions and the wider community, Ethiopia. The current study also reported farhigher than the other reports from Afar region that were $12.3 \%$ in 2005 , and $12.7 \%$ in 2011 (17). The present study is higher than a study that conducted in Somalia, Benishangul, and Gambella regions (17). The difference might be as a result of study population and data collection methods difference. The former studies were a passive survey among motherchild pair who visited health facility that contradicts with the present active community survey. The current study is lower than the UN Inter-Agency Group report, 31.4\% in 2016 at South-Eastern Asia(16). The difference might be as a result of thatthe current study is a proximate prevalence that might be biased because of recall bias, and social desirability bias.

In addition to the above general description, we considered the total prevalence of mortality by gender. In the 2016 EDHS data collection, the total number of children died in the house despite the year that children died were considered. This might create discomfort for mothers who lost many children. Thus, we analyzed the mortality data by sex independently.Accordingly, the prevalence of under-five mortality among daughters was $15.4 \%, 95 \% \mathrm{Cl}(14.2,16.6 \%)$, and among sons was $16.8 \%, 95 \% \mathrm{Cl}(15.6,18.1 \%)$. The current prevalence among sons and daughters were almost similar by consensus but in $95 \% \mathrm{Cl}$, the mortality among boys was high. However, we discussed the prevalence of under-five mortality in considering the lower confidence interval of daughters, and the upper confidence interval of sons $(14.2,18.1)$. The separate prevalence among daughters and sons might be more precise than the aggregate prevalence reported despite the sex of children.

Accordingly, the current prevalence of U5M is higher than a study conducted in west Africa and that reported $11.1 \%$ in Sierra Leone, Nigeria 10.0\%, Mali 10.6\%, and in Cape Verde 1.7\%(18). The difference might be as a result of study population, and socio-economic dissimilarity. The former study considered children despite their sex, however this study's analysis focus on male or female children from poorest regions of Ethiopia separately. Thepresent study's prevalence is consistent with a decomposition analysis conducted in Sub- 
Saharan Africa in considering Benin, Chad, Congo, Côte d'Ivoire, Ethiopia, Gabon, Malawi, Mozambique, Rwanda, Sierra Leone, Uganda, and Zambia. The analysis indicated the presence of inequalities between under-five boys' and girls' mortality that reported high boy mortality(19), which is true for this study, even the difference is not too ample. This variation in boys and girls mortality also supported by other study(20), in which all the reports indicated that boys were more affected. The justification for such variation between girls and boys might be because of biological factors (boys lower resistance to infection, and higher risk of premature birth), and gender discrimination (differential feeding and medication)(21, 22). There is also a study that supported the difference of U5M among sons and girls in Ethiopia(23). In contrary, a study in Ethiopia indicated a lack of significant difference of under-five death between males and females(24).The variation might be as result of study design difference, in which the former study used a case-control design. The case control design is not appropriate to report magnitude than cross-section design.

In assessing the association of under-five mortality with predictors, we consider the gender of children. Initially, the study tries to assess the association of U5M irrespective of the deceased child's gender. Beyond this, we try to assess the association of U5M among daughters and among sons independently. The assumption we considered is that the factors for daughters and sons might have difference. Therefore, in the final logistic regression model, female head of households ((AOR), $95 \% \mathrm{Cl}(0.76),(0.63,0.91)$ have a preventive association with U5M in those pastoralist regions. The head of households were also associated with both sons and daughters mortality when we assessed the effect by sex. Female household heads $((0.74),(0.60,0.93)$ were decreasing the odds of under-five daughters mortality. These was also true that female household heads $((0.0 .80,(0.0 .65,0.0 .99)$ were decreasing the odds of under-five sons mortality. A wealth index of poorest $((2.20), 1.42,3.41)$, poorer $((2.72),(1.70,4.33)$, or richer $((1.77),(1.09,2.86)$ in relative to richest wealth index increase the odds of U5C mortality (25-30) irrespective of child sex. This degree of association were also happened when we assessed the association with either sons or daughters mortality in considering the gender of children. $\boldsymbol{A}$ wealth index of poorest ((1.90), (1.24, 2.89), or poorer ((1.94), (1.20, 3.16) households increase the odds of under-five daughters mortality. Similarly, the wealth index of poorest $((2.14),(1.27,3.64)$, or poorer $((3.02),(1.74,5.24)$ household status increase the likelihood of under-five sons mortality.Husbands who drop from secondary education increase the chance of their U5C mortality ((1.54), $(0.34,0.86)$ than husband who completed higher education. The result was consistent with a number of studies $(26,27,29)$. The association was also happed in either sons or daughters separate analysis, but the association was preventive. Husband education, incomplete secondary school, ((AOR), (95\% Cl), ((0.38), (0.21, $0.70)$ prevent the odds of under-five sons mortality. Husband education, unable to read and write, ((AOR), (95\% Cl), ((1.67), $(1.03,2.70)$ increase the odds daughters mortality in the pastoralist regions.Children whose age was birth to 12 months $((0.72),(0.56,0.92)$ were less likely to die than 48 to 59 months old children irrespective of the child sex. This association was repeated when the daughters' dataset analyzed. Female children whose age was birth to 12 months $((0.63),(0.47,0.85)$ were less likely to die than 48 to 59 months old children. Having multiple birth $((2.39),(1.25,4.56)$ during the first parity increase under-five mortality compared to singleton. This is similar with a study conducted from 2016 EDHS at national level that reported an odds of under-five mortality $(\mathrm{AOR}=4.74, \mathrm{Cl}=[3.34,6.69], P<0.000)$ in multiple births compared to singletons $(5,23,31-33)$. This association was also repeated when we assess the daughters dataset that multiple births during the first parity $((2.61),(1.29,5.23)$, and second parity $((2.30),(1.11,4.76)$ predisposed under-five daughters to mortality than single births.In the daughters data set, female children born from 
Muslim $((2.70),(1.64,4.44)$ family were more likely to die than Ethiopian orthodox religion follower.Similarly, the sons' data set indicated that male children born from Muslim ((2.04), (1.28, 3.23), Catholic ((17.75), (5.85, $53.86)$, and other religion followers $((6.01),(2.12,16.73)$ were more likely to die than Ethiopian orthodox religion follower. Average child size at birth $((0.68),(0.51,0.90)$ prevent under-five daughters mortality than very large daughters at birth. This agreed with a study derived from the 2016 EDHS data $(5,30$, 34). Unplanned birth $((1.70),(1.03,2.81)$ increase the likelihood of sons death than planned births. This contradict with a study that reported a preventive association(26). But this association is consistent with a study that reported from India $(27,35)$. History of short, and rapid breathing ((1.74), $(1.22,2.48)$ increase the probability of under-five sons' death than children who had not it. This association is supported by WHO report that indicated respiratory infections were one of the causes of U5M(36). Unlike the previous study conducted in Ethiopia(31), none of the pastoralist region have no association with U5M. Since the causes of high under-five mortality in resource poor settings are complex and merit concerted efforts to clarify their implications to improve child survival(37), we try to evaluate the prevalence of U5M by selecting the most susceptible areas and identified factors through triangulating the data set by sex as mentioned above. The government of Ethiopia and the pastoralist regions will utilize this evidence to draft police as per the following recommendation we stated in the conclusion section.

\section{Conclusion}

The prevalence of under-five child mortality in the pastoralist regions of Ethiopia was high, which was far highest in relative to the national under-five mortality prevalence. The proportion of male to female child mortality was nearly 1 . In assessing the effect of variables on under-five child mortality by gender, almost all the variables that have effect on female and male children are similar. For example, wealth indexand husband education were associated with daughters, sons, as well as both male and female children aggregate mortality irrespective of sex. Multiple birth and age of children were associated with U5M, and increases the odds of U5M among daughters in assessing the association by sex. Religion was associated with U5M in the pastoralist regions. Thus, the government should emphasize on the pastoralists' regions to decrease the high prevalence of under-five child mortality.

\section{Limitations}

The 2016 EDHS collected a crude child death data that was not limited to definite years. Thus, the prevalence of child mortality in this study indicated a total death of children among mothers who enrolled in this study who have also under-five children at the time of data collection. This indicates that the prevalence of underfive mortality in this study might not be a precise indicator of child mortality. But, it indicates how many of mothers lost female children or and male children in their lifetimes up to the 2016 EDHS data collection takes placed. The other limitation of this study was the repetition of mothers' report while they complain for both male and female child deaths. However, we try to analyze the data separately for male and female child death.

\section{Declarations}




\section{Ethics approval and consent to participate}

Not applicable

\section{Consent for publication}

Not applicable

\section{Availability of data and materials}

The raw materials that support the conclusions of this research can uploaded as a supplementary file together with the manuscript documents.

\section{Competing interests}

The authors declare that they have no conflict of interests

\section{Funding}

Not applicable

\section{Authors' contributions}

For this study MWK, SAM, AMA, AMK, and BBA Conceived the title and designed the study, preparing a complex data for analysis, analyzing the complex data, critically revising the work and writing the final manuscript. All the authors read and approved the final version of this manuscript. The authors agreed to be accountable for all aspects of this work.

\section{Acknowledgements}

We would like to acknowledge the central statistical agency of Ethiopia for the data (EDHS) they collected and proviside it online in collaboration with the USAID.

\section{References}

1. Hug L, Sharrow D, You D. Levels \& Trends in Child Mortality: Report. Estimates Developed by the UN Interagency Group for Child Mortality Estimation. United Nations Inter-Agency Group for Child Mortality Estimation, New York ...; 2017.

2. Unicef. Levels and Trends in Child Mortality: Report 2010: Estimates Developed by the UN Inter-Agency Group for Child Mortality Estimation: United Nations Children's Fund; 2010.

3. Deribew A, Tessema GA, Deribe K, Melaku YA, Lakew Y, Amare AT, et al. Trends, causes, and risk factors of mortality among children under 5 in Ethiopia, 1990-2013: findings from the Global Burden of Disease Study 2013. Population health metrics. 2016;14(1):42.

4. Organization WH. United Arab Emirates health profile 2015. World Health Organization. Regional Office for the Eastern Mediterranean; 2016. 
5. Fikru C, Getnet M, Shaweno T. Proximate Determinants of Under-Five Mortality in Ethiopia: Using 2016 Nationwide Survey Data. Pediatric Health, Medicine and Therapeutics. 2019;10:169.

6. McGuire JW. Basic health care provision and under-5 mortality: a cross-national study of developing countries. World Development. 2006;34(3):405-25.

7. WHO. Children: reducing mortality. WHO. 2019.

8. Doherty T, Rohde S, Besada D, Kerber K, Manda S, Loveday M, et al. Reduction in child mortality in Ethiopia: analysis of data from demographic and health surveys. Journal of global health. 2016;6(2).

9. EDHS E. demographic and health survey 2016: key indicators report. The DHS Program ICF. 2016;363:364.

10. UNICEF Ca. Multidimensional Child Deprivation in Ethiopia. First National Estimates. 2018:100.

11. Icf C. Ethiopian demographic health survey 2011. Addis Ababa and Calverton: Central Statistical Agency (Ethiopia) and ICF International. 2012:17-27.

12. Nations U. Transforming our world: The 2030 agenda for sustainable development. General Assembley 70 session. 2015.

13. YD. W. Women's autonomy and reproductive health-care-seeking behavior in Ethiopia. Women \& health. 2017:1-15.

14. G. P. Do conditional cash transfers improve child health? Evidence from PROGRESA's control randomized experiment. Am Econ Rev. 2004;94(33641):22.

15. You D, Hug L, Ejdemyr S, Idele P, Hogan D, Mathers C, et al. Global, regional, and national levels and trends in under-5 mortality between 1990 and 2015, with scenario-based projections to 2030: a systematic analysis by the UN Inter-agency Group for Child Mortality Estimation. The Lancet. 2015;386(10010):2275-86.

16. Estimation UNIGfCM. Levels \& Trends in Child Mortality: Report 2017: Estimates Developed by the UN Inter-Agency Group for Child Mortality Estimation: United Nations Children's Fund; 2017.

17. Negera A, Abelti G, Bogale T, Gebreselassie T, Pearson R. An analysis of the trends, differentials and key proximate determinants of infant and under-five mortality in Ethiopia. ICF International: Calverton, Maryland USA. 2013.

18. Sanyang Y. Prevalence of Under-Five Years of Age Mortality by Infectious Diseases in West African Region. International Journal of Africa Nursing Sciences. 2019:100175.

19. Alkema L, Chao F, You D, Pedersen J, Sawyer CC. National, regional, and global sex ratios of infant, child, and under-5 mortality and identification of countries with outlying ratios: a systematic assessment. The Lancet Global Health. 2014;2(9):e521-e30.

20. Boco AG. Assessing sex differentials in under-five mortality in sub-Saharan Africa: A cross-national comparative analysis. Canadian Studies in Population [ARCHIVES]. 2014;41(3-4):49-87.

21. Drevenstedt GL, Crimmins EM, Vasunilashorn S, Finch CE. The rise and fall of excess male infant mortality. Proceedings of the National Academy of Sciences. 2008;105(13):5016-21.

22. Yaya S, Diarra S, Mabeu MC, Pongou R. The sex gap in neonatal mortality and the AIDS epidemic in subSaharan Africa. BMJ global health. 2018;3(5):e000940. 
23. Berelie Y, Yismaw L, Tesfa E, Alene M. Risk factors for under-five mortality in Ethiopia: Evidence from the 2016 Ethiopian Demographic and Health Survey. South African Journal of Child Health. 2019;13(3):13740.

24. Deribew A, Tessema F, Girma B. Determinants of under-five mortality in Gilgel gibe field research center, Southwest Ethiopia. Ethiopian Journal of Health Development. 2007;21(2):117-24.

25. Moser KA, Leon DA, Gwatkin DR. How does progress towards the child mortality millennium development goal affect inequalities between the poorest and least poor? Analysis of Demographic and Health Survey data. Bmj. 2005;331(7526):1180-2.

26. Bendavid E. Changes in child mortality over time across the wealth gradient in less-developed countries. Pediatrics. 2014;134(6):e1551-e9.

27. Sohail H, Neupane S. Prevalence of and factors associated with under-5 mortality in South Asia. International health. 2019;11(2):119-27.

28. Dendup T, Zhao Y, Dema D. Factors associated with under-five mortality in Bhutan: an analysis of the Bhutan National Health Survey 2012. BMC public health. 2018;18(1):1375.

29. Yaya S, Ekholuenetale M, Tudeme G, Vaibhav S, Bishwajit G, Kadio B. Prevalence and determinants of childhood mortality in Nigeria. BMC public health. 2017;17(1):485.

30. Yaya S, Bishwajit G, Okonofua F, Uthman OA. Under five mortality patterns and associated maternal risk factors in sub-Saharan Africa: A multi-country analysis. PloS one. 2018;13(10).

31. Woldeamanuel BT. Socioeconomic, Demographic, and Environmental Determinants of Under-5 Mortality in Ethiopia: Evidence from Ethiopian Demographic and Health Survey, 2016. Child Development Research. 2019;2019:1073782.

32. Aheto JMK. Predictive model and determinants of under-five child mortality: evidence from the 2014 Ghana demographic and health survey. BMC public health. 2019;19(1):64.

33. Organization WH. World health statistics 2015: World Health Organization; 2015.

34. Mani K, Dwivedi SN, Pandey RM. Determinants of under-five mortality in rural empowered action group states in India: an application of cox frailty model. International Journal of MCH and AIDS. 2012;1(1):60.

35. Singh A, Singh A, Mahapatra B. The consequences of unintended pregnancy for maternal and child health in rural India: evidence from prospective data. Maternal and child health journal. 2013;17(3):493500.

36. Phukan P, Jagtap A, Nagaraj SB. Child health related millennium development goals (MDGs): status of under five children visiting a well baby camp. Int J Med Sci Public Health. 2014;3:1064-8.

37. Kanmiki EW, Bawah AA, Agorinya I, Achana FS, Awoonor-Williams JK, Oduro AR, et al. Socio-economic and demographic determinants of under-five mortality in rural northern Ghana. BMC international health and human rights. 2014;14(1):24.

\section{Tables}

Table1: The socio-demographic characteristics of respondents in assessing under-five children mortality in the pastoralist regions, Ethiopia $(n=3527)$ 


\begin{tabular}{|c|c|c|c|}
\hline Variable & Categories & Frequency & Percent \\
\hline \multirow[t]{9}{*}{ Husband occupation } & Did not work & 2385 & 67.6 \\
\hline & Professional/managerial & 47 & 1.3 \\
\hline & Clerical & 4 & 0.1 \\
\hline & Sales & 247 & 7.0 \\
\hline & Agricultural employee & 626 & 17.7 \\
\hline & Service & 35 & 1.0 \\
\hline & Skilled manual & 73 & 2.1 \\
\hline & Unskilled manual & 66 & 1.9 \\
\hline & Other & 44 & 1.2 \\
\hline \multirow[t]{9}{*}{ Maternal occupation } & Did not work & 637 & 18.1 \\
\hline & Professional/managerial & 352 & 10.0 \\
\hline & Clerical & 30 & 0.9 \\
\hline & Sales & 237 & 6.7 \\
\hline & Agricultural employee & 1641 & 46.5 \\
\hline & Service & 147 & 4.2 \\
\hline & Skilled manual & 142 & 4.0 \\
\hline & Unskilled manual & 142 & 4.0 \\
\hline & Other & 199 & 5.6 \\
\hline \multirow[t]{2}{*}{ Head of household } & Male & 2537 & 71.9 \\
\hline & Female & 990 & 28.1 \\
\hline \multirow[t]{2}{*}{ Residence } & Urban & 519 & 14.7 \\
\hline & Rural & 3008 & 85.3 \\
\hline \multirow[t]{7}{*}{ Maternal age } & $15-19$ & 146 & 4.1 \\
\hline & $20-24$ & 805 & 22.8 \\
\hline & $25-29$ & 1065 & 30.2 \\
\hline & $30-34$ & 750 & 21.3 \\
\hline & $35-39$ & 519 & 14.7 \\
\hline & $40-44$ & 179 & 5.1 \\
\hline & $45-49$ & 63 & 1.8 \\
\hline
\end{tabular}

Page $11 / 23$ 


\begin{tabular}{|c|c|c|c|}
\hline \multirow[t]{4}{*}{ Maternal education } & No education & 2593 & 73.5 \\
\hline & Primary & 664 & 18.8 \\
\hline & Secondary & 194 & 5.5 \\
\hline & Higher & 76 & 2.2 \\
\hline \multirow[t]{6}{*}{ Husband education } & No education & 2171 & 61.6 \\
\hline & Incomplete primary & 607 & 17.2 \\
\hline & Complete primary & 121 & 3.4 \\
\hline & Incomplete secondary & 277 & 7.9 \\
\hline & Complete secondary & 55 & 1.6 \\
\hline & Higher & 296 & 8.4 \\
\hline \multirow[t]{6}{*}{ Religion } & Orthodox & 285 & 8.1 \\
\hline & Catholic & 16 & 0.5 \\
\hline & Protestant & 571 & 16.2 \\
\hline & Muslim & 2574 & 73.0 \\
\hline & Traditional & 59 & 1.7 \\
\hline & Other & 22 & 0.6 \\
\hline \multirow[t]{5}{*}{ Wealth index } & Poorest & 2224 & 63.1 \\
\hline & Poorer & 389 & 11.0 \\
\hline & Middle & 258 & 7.3 \\
\hline & Richer & 253 & 7.2 \\
\hline & Richest & 403 & 11.4 \\
\hline \multirow[t]{3}{*}{ Readiness } & Wanted then & 3168 & 89.8 \\
\hline & Wanted later & 262 & 7.4 \\
\hline & Wanted no more & 97 & 2.8 \\
\hline \multirow[t]{2}{*}{ Cigarette smoking } & No & 3479 & 98.6 \\
\hline & Yes & 48 & 1.4 \\
\hline \multirow[t]{2}{*}{ Chat chewing } & No & 3420 & 97.0 \\
\hline & Yes & 107 & 3.0 \\
\hline \multirow[t]{2}{*}{ Type of birth } & Single birth & 3447 & 97.7 \\
\hline & $1^{\text {st }}$ of multiple & 41 & 1.2 \\
\hline
\end{tabular}




\begin{tabular}{|c|c|c|c|}
\hline & $2^{\text {nd }}$ of multiple & 39 & 1.1 \\
\hline \multirow[t]{2}{*}{ Sex of the child } & Male & 1836 & 52.1 \\
\hline & Female & 1691 & 47.9 \\
\hline \multirow[t]{5}{*}{ Child age } & Birth to 12 & 764 & 21.7 \\
\hline & 12 to 24 & 637 & 18.1 \\
\hline & 24 to 36 & 714 & 20.2 \\
\hline & 36 to 48 & 690 & 19.6 \\
\hline & 48 to 59 & 722 & 20.5 \\
\hline \multirow[t]{2}{*}{ Fast, and rapid breathing } & No & 3340 & 94.7 \\
\hline & Yes & 187 & 5.3 \\
\hline \multirow[t]{2}{*}{ Child lives with whom } & Respondent & 3524 & 99.9 \\
\hline & Lives elsewhere & 3 & 0.1 \\
\hline \multirow[t]{2}{*}{ Marital status } & Married & 3505 & 99.4 \\
\hline & Living with partner & 22 & 0.6 \\
\hline \multirow[t]{2}{*}{ Delivery by caesarean section } & No & 3504 & 99.3 \\
\hline & Yes & 23 & 0.7 \\
\hline \multirow[t]{5}{*}{ Size of child } & Very large & 462 & 13.1 \\
\hline & Large & 515 & 14.6 \\
\hline & Average & 1492 & 42.3 \\
\hline & Small & 367 & 10.4 \\
\hline & Very small & 691 & 19.6 \\
\hline \multirow[t]{2}{*}{ Place of birth } & Home & 2711 & 76.9 \\
\hline & Health facility & 816 & 23.1 \\
\hline
\end{tabular}

Table2: The number of under-five children deaths by sex in the pastoralist communities, Ethiopia, $(n=3527)$ 


\begin{tabular}{|lll|}
\hline Number of death & Daughters (\%) & Sons \\
\hline 0 & $2984(84.6 \%)$ & $2934(83.2 \%)$ \\
\hline 1 & $422(12.0 \%)$ & $438(12.4 \%)$ \\
\hline 2 & $100(2.8 \%)$ & $108(3.1 \%)$ \\
\hline 4 & $17(0.5 \%)$ & $38(1.1 \%)$ \\
\hline Total death & $4(0.1 \%)$ & $9(0.3 \%)$ \\
\hline
\end{tabular}

\section{Table3:}




\begin{tabular}{|c|c|c|c|c|c|c|c|c|}
\hline \multirow[t]{2}{*}{ Variable } & \multirow[t]{2}{*}{ Categories } & \multicolumn{2}{|c|}{ Childhood mortality } & \multicolumn{2}{|l|}{ OR } & \multicolumn{2}{|c|}{$95 \% \mathrm{Cl}$} & \multirow{2}{*}{$\begin{array}{l}\mathrm{P} \text { - } \\
\text { value }\end{array}$} \\
\hline & & Alive & Died & COR & AOR & Lower & Upper & \\
\hline \multirow{5}{*}{$\begin{array}{l}\text { Wealth } \\
\text { index }\end{array}$} & Poorest & 1664(74.8) & $560(25.2)$ & $2.18^{\star}$ & 2.20 & 1.42 & 3.41 & 0.001 \\
\hline & Poorer & $283(72.8)$ & $106(27.2)$ & $2.42^{\star}$ & 2.72 & 1.70 & 4.34 & 0.001 \\
\hline & Medium & $212(82.2)$ & $46(17.8)$ & 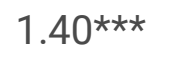 & 1.53 & 0.92 & 2.55 & 0.105 \\
\hline & Richer & 202(79.8) & $51(20.2)$ & $1.63^{\star \star}$ & 1.77 & 1.10 & 2.86 & 0.020 \\
\hline & Richest & $349(86.6)$ & $54(13.4)$ & Ref & Ref & - & - & Ref \\
\hline \multirow[t]{2}{*}{ Residence } & Rural & $428(82.5)$ & $91(17.5)$ & $1.50 *$ & 0.90 & 0.64 & 1.28 & 0.57 \\
\hline & Urban & 2282(75.9) & $726(24.1)$ & Ref & Ref & - & - & Ref \\
\hline \multirow[t]{2}{*}{ Smoking } & No & $2670(76.7)$ & $809(23.3)$ & Ref & Ref & - & - & Ref \\
\hline & Yes & $40(83.3)$ & $8(16.7)$ & 0.66 & 0.65 & 0.30 & 1.40 & 0.27 \\
\hline \multirow{2}{*}{$\begin{array}{l}\text { Head of } \\
\text { household }\end{array}$} & Male & 1918(75.6) & $619(24.4)$ & Ref & Ref & - & - & Ref \\
\hline & Female & 792(80.0) & 198(20.0) & $1.43 * \star \star$ & 0.76 & 0.63 & 0.91 & 0.004 \\
\hline \multirow[t]{3}{*}{$\begin{array}{l}\text { Was child } \\
\text { wanted }\end{array}$} & $\begin{array}{l}\text { Wanted } \\
\text { then }\end{array}$ & 2430(76.7) & 738(23.3) & Ref & Ref & & & Ref \\
\hline & $\begin{array}{l}\text { Wanted } \\
\text { latter }\end{array}$ & 209(79.8) & $53(20.2)$ & 0.84 & 0.97 & 0.70 & 1.35 & 0.86 \\
\hline & $\begin{array}{l}\text { Wanted no } \\
\text { more }\end{array}$ & 71(73.2) & $26(26.8)$ & 1.21 & 1.16 & 0.72 & 1.87 & 0.54 \\
\hline \multirow[t]{2}{*}{$\begin{array}{l}\text { Marital } \\
\text { status }\end{array}$} & Married & $\begin{array}{l}2693 \\
(76.8)\end{array}$ & 812 (23.2) & Ref & Ref & - & - & Ref \\
\hline & $\begin{array}{l}\text { Live with } \\
\text { partner }\end{array}$ & 17(77.3) & $5(22.7 \%)$ & 0.98 & 1.40 & 0.50 & 3.92 & 0.53 \\
\hline \multirow[t]{2}{*}{$\begin{array}{l}\text { Khat } \\
\text { chewing }\end{array}$} & No & $\begin{array}{l}2635 \\
(77.0)\end{array}$ & $785(23.0)$ & Ref & Ref & - & - & Ref \\
\hline & Yes & $75(70.1)$ & $32(29.9)$ & $1.43^{\star \star \star}$ & $1.43^{\star \star \star}$ & 1.08 & 2.60 & 0.02 \\
\hline \multirow[t]{2}{*}{ Child sex } & Male & 1422(77.5) & $414(22.5 \%)$ & Ref & - & - & - & - \\
\hline & Female & 1288(76.2) & $403(23.8 \%)$ & 1.08 & -- & - & - & - \\
\hline \multirow{3}{*}{$\begin{array}{l}\text { Type of } \\
\text { child birth }\end{array}$} & Single birth & 2661(77.2) & $786(22.8)$ & Ref & Ref & - & - & Ref \\
\hline & $\begin{array}{l}1 \text { st of } \\
\text { multiple }\end{array}$ & $24(58.5)$ & $17(41.5)$ & 2.40 ** & 2.39 & 1.25 & 4.56 & 0.008 \\
\hline & $\begin{array}{l}\text { 2nd of } \\
\text { multiple }\end{array}$ & $25(64.1)$ & 14(35.9) & 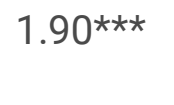 & 1.85 & 0.94 & 3.63 & 0.07 \\
\hline Child age & Birth to 12 & $612(80.1)$ & 152(19.9) & 0.71 ** & 0.72 & 0.56 & 0.92 & 0.009 \\
\hline
\end{tabular}




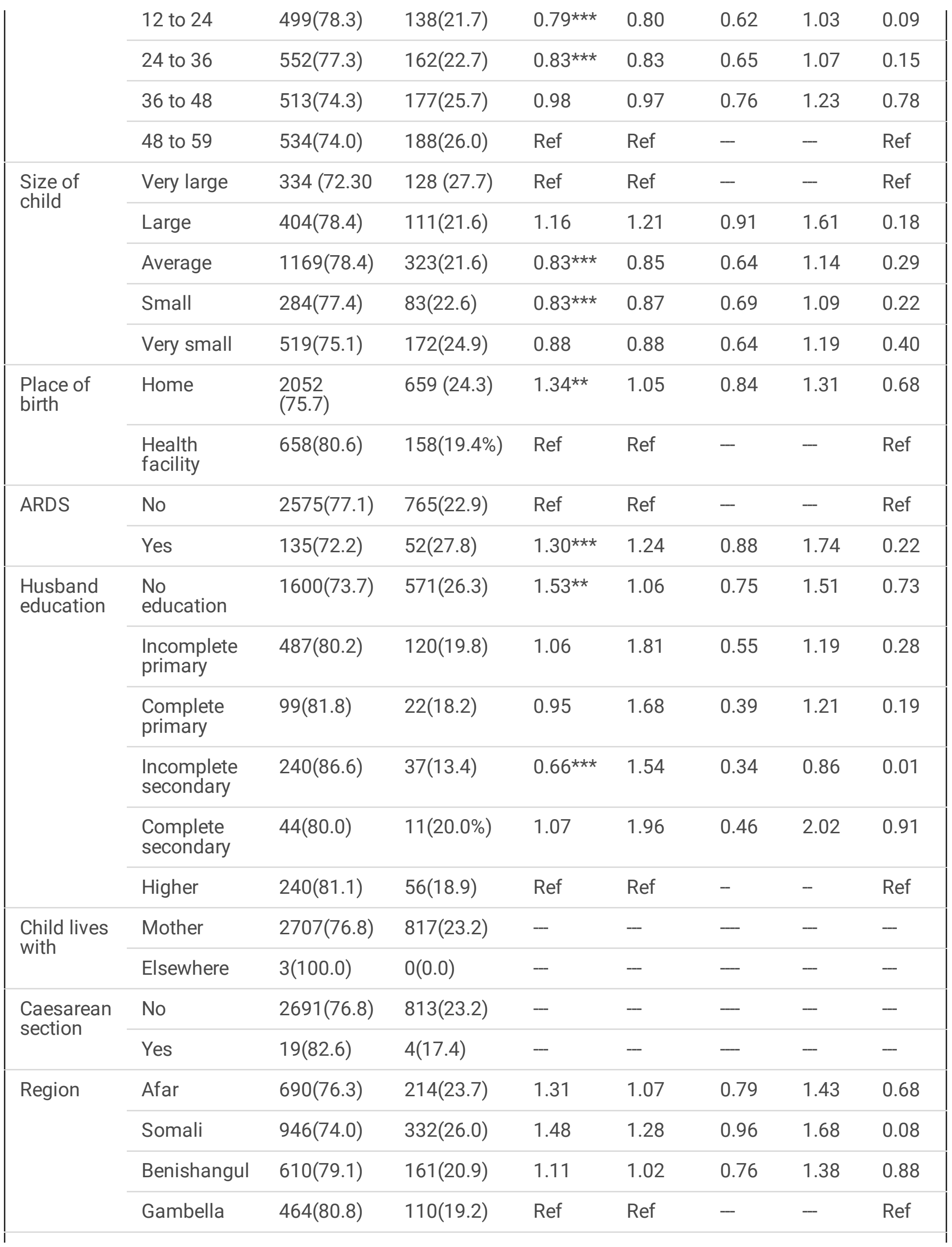




\begin{tabular}{|lllllllll|} 
Maternal & $15-19$ & $140(95.9)$ & $6(4.1)$ & - & - & - & - & - \\
\cline { 2 - 8 } & $20-24$ & $714(88.7)$ & $91(11.3)$ & - & - & - & - & - \\
\hline $25-29$ & $857(80.5)$ & $208(19.5)$ & - & - & - & - & - \\
& $30-34$ & $531(70.8)$ & $219(29.2)$ & - & - & - & - & - \\
\hline $35-39$ & $337(64.9)$ & $182(35.1)$ & - & - & - & - & - \\
& $40-44$ & $100(55.9)$ & $79(44.1)$ & - & - & - & - & - \\
\hline $45-49$ & $31(49.2)$ & $32(50.8)$ & - & - & - & - & - \\
\hline
\end{tabular}

$N B:{ }^{*}=P<0.001,{ }^{*}=p<0.05, * \star *=p<=0.20$

Table4: The association of under-five sons mortality and potential determinates in the pastoralist communities, Ethiopia $(n=3527)$ 


\begin{tabular}{|c|c|c|c|c|c|c|c|c|}
\hline \multirow[t]{2}{*}{ Variable } & \multirow[t]{2}{*}{ Categories } & \multicolumn{2}{|c|}{ Childhood mortality } & \multicolumn{2}{|l|}{ OR } & \multicolumn{2}{|l|}{$95 \% \mathrm{Cl}$} & \multirow{2}{*}{$\begin{array}{l}\mathrm{P} \text { - } \\
\text { value }\end{array}$} \\
\hline & & Alive & Died & COR & AOR & Lower & Upper & \\
\hline \multirow{5}{*}{$\begin{array}{l}\text { Wealth } \\
\text { index }\end{array}$} & Poorest & 1818(81.7) & $406(18.3)$ & $2.28 * \star$ & 2.14 & 1.27 & 3.64 & 0.05 \\
\hline & Poorer & $298(76.6)$ & $91(23.4)$ & $3.11^{\star *}$ & 3.02 & 1.74 & 5.24 & 0.001 \\
\hline & Medium & 228(88.4) & $30(11.6)$ & 1.34 & 1.29 & 0.70 & 2.40 & 0.42 \\
\hline & Richer & 223(88.1) & $30(11.9)$ & 1.37 & 1.32 & 0.73 & 2.37 & 0.36 \\
\hline & Richest & $367(91.1)$ & $36(8.9)$ & Ref & Ref & - & - & Ref \\
\hline \multirow[t]{2}{*}{ Residence } & Rural & 2473(82.2) & $535(17.8)$ & $1.72^{\star}$ & 0.90 & 0.59 & 1.36 & 0.61 \\
\hline & Urban & $461(88.8)$ & $58(11.2)$ & Ref & Ref & - & - & Ref \\
\hline \multirow[t]{2}{*}{ Smoking } & No & $2892(83.1)$ & $587(16.9)$ & Ref & - & - & - & - \\
\hline & Yes & $42(87.5)$ & $6(12.5)$ & 0.70 & - & - & - & - \\
\hline \multirow[t]{6}{*}{ Religion } & Orthodox & $256(89.8)$ & $29(10.2)$ & Ref & Ref & - & - & Ref \\
\hline & Catholic & $7(43.8)$ & $9(56.2)$ & $11.35^{\star}$ & 17.75 & 5.85 & 53.87 & 0.001 \\
\hline & Protestant & 499(87.4) & 72(12.6) & 1.27 & 1.45 & .852 & 2.462 & 0.17 \\
\hline & Muslim & $2107(81.9)$ & $467(18.1)$ & $1.96^{*}$ & 2.04 & 1.28 & 3.23 & 0.01 \\
\hline & Traditional & $51(86.4)$ & $8(13.6)$ & 1.39 & 1.23 & 0.52 & 2.92 & 0.63 \\
\hline & Other & 14 (63.6) & $8(36.4)$ & $5.04^{*}$ & 5.96 & 2.12 & 16.73 & 0.001 \\
\hline \multirow{2}{*}{$\begin{array}{l}\text { Head of } \\
\text { household }\end{array}$} & Male & $2089(82.3)$ & $448(17.7)$ & Ref & Ref & - & - & Ref \\
\hline & Female & $845(85.4)$ & $145(14.6)$ & $0.80 * \star$ & 0.80 & 0.65 & 0.99 & 0.04 \\
\hline \multirow{3}{*}{$\begin{array}{l}\text { Was child } \\
\text { wanted }\end{array}$} & Wanted then & $2637(83.2)$ & $531(16.8)$ & Ref & Ref & - & - & Ref \\
\hline & Wanted latter & $223(85.1)$ & $39(14.9)$ & 0.87 & 1.02 & 0.70 & 1.49 & 0.92 \\
\hline & $\begin{array}{l}\text { Wanted no } \\
\text { more }\end{array}$ & 74(76.3) & 23(23.7) & $1.54^{\star \star \star}$ & 1.70 & 1.03 & 2.81 & 0.04 \\
\hline \multirow{2}{*}{$\begin{array}{l}\text { Marital } \\
\text { status }\end{array}$} & Married & 2915(83.2) & $590(16.8)$ & Ref & - & - & - & - \\
\hline & $\begin{array}{l}\text { Live with } \\
\text { partner }\end{array}$ & 19(86.4) & $3(13.6)$ & 0.78 & - & - & - & - \\
\hline \multirow{2}{*}{$\begin{array}{l}\text { Kcat } \\
\text { chewing }\end{array}$} & No & $2846(83.2)$ & $574(16.8)$ & Ref & - & - & - & - \\
\hline & Yes & $88(82.2)$ & 19(17.8) & 1.07 & - & - & - & - \\
\hline \multirow[t]{2}{*}{ Child sex } & Male & 1548(84.3) & 288(15.7) & Ref & - & - & - & - \\
\hline & Female & $1386(82.0)$ & $305(18.0)$ & 1.18 & - & - & - & - \\
\hline Child birth & Single birth & $\begin{array}{l}2875 \\
(83.4)\end{array}$ & $\begin{array}{l}572 \\
(16.6)\end{array}$ & Ref & Ref & - & - & Ref \\
\hline
\end{tabular}




\begin{tabular}{|c|c|c|c|c|c|c|c|c|}
\hline & $\begin{array}{l}1^{\text {st }} \text { of } \\
\text { multiple }\end{array}$ & $31(75.6)$ & $10(24.4)$ & $1.62^{\star \star \star}$ & 1.59 & 0.76 & 3.36 & 0.22 \\
\hline & $\begin{array}{l}2^{\text {nd }} \text { of } \\
\text { multiple }\end{array}$ & $28(71.8)$ & $11(28.2)$ & $1.98^{\star \star \star}$ & 1.92 & 0.93 & 3.97 & 0.08 \\
\hline \multirow{5}{*}{$\begin{array}{l}\text { Child age in } \\
\text { months }\end{array}$} & Birth to 12 & $642(84.0)$ & $122(16.0)$ & 0.89 & - & - & - & - \\
\hline & 12 to 24 & $537(84.3)$ & $100(15.7)$ & 0.87 & - & - & - & - \\
\hline & 24 to 36 & $597(83.6)$ & $117(16.4)$ & 0.92 & - & - & - & - \\
\hline & 36 to 48 & $563(81.6)$ & 127(18.4) & 1.06 & - & - & - & - \\
\hline & 48 to 59 & $595(82.4)$ & $127(17.6)$ & Ref & - & - & - & - \\
\hline \multirow[t]{5}{*}{ Size of child } & Very large & $386(83.5)$ & $76(16.5)$ & Ref & Ref & - & - & Ref \\
\hline & Large & $448(87.0)$ & $67(13.0)$ & $0.76^{\star \star \star}$ & 0.75 & 0.52 & 1.08 & 0.12 \\
\hline & Average & $1232(82.6)$ & $260(17.4)$ & 1.07 & 1.07 & 0.80 & 1.42 & 0.67 \\
\hline & Small & $305(83.1)$ & $62(16.9)$ & 1.03 & 0.96 & 0.66 & 1.41 & 0.84 \\
\hline & Very small & $563(81.5)$ & $128(18.5)$ & 1.16 & 1.05 & 0.75 & 1.46 & 0.79 \\
\hline \multirow{2}{*}{$\begin{array}{l}\text { Place of } \\
\text { birth }\end{array}$} & Home & $2232(82.3)$ & 479(17.7) & $1.32^{\star \star}$ & 1.06 & 0.82 & 1.37 & 0.66 \\
\hline & $\begin{array}{l}\text { Health } \\
\text { facility }\end{array}$ & $702(86.0)$ & $114(14.0)$ & Ref & Ref & - & - & Ref \\
\hline \multirow{2}{*}{$\begin{array}{l}\text { Short, and } \\
\text { rapid } \\
\text { breathing }\end{array}$} & No & $\begin{array}{l}2795 \\
(83.7)\end{array}$ & $545(16.3)$ & Ref & Ref & - & - & Ref \\
\hline & Yes & $139(74.3)$ & $48(25.7)$ & $1.77^{*}$ & 1.74 & 1.22 & 2.48 & 0.01 \\
\hline \multirow{4}{*}{$\begin{array}{l}\text { Maternal } \\
\text { education }\end{array}$} & No education & $2106(81.2)$ & 487(18.8) & $8.56^{\star \star}$ & - & - & - & - \\
\hline & Primary & $584(88.0)$ & $80(12.0)$ & $5.07 \star \star$ & - & - & - & - \\
\hline & Secondary & 170(87.6) & $24(12.4)$ & $5.22^{\star \star}$ & - & - & - & - \\
\hline & Higher & $74(97.4)$ & $2(2.6)$ & Ref & - & - & - & - \\
\hline \multirow{6}{*}{$\begin{array}{l}\text { Husband } \\
\text { education }\end{array}$} & No education & $1760(81.1)$ & 411(18.9) & $1.50 \star \star$ & 1.13 & 0.75 & 1.70 & 0.57 \\
\hline & $\begin{array}{l}\text { Incomplete } \\
\text { primary }\end{array}$ & $503(82.9)$ & 104(17.1) & $1.32^{\star \star *}$ & 1.05 & 0.67 & 1.64 & 0.83 \\
\hline & $\begin{array}{l}\text { Complete } \\
\text { primary }\end{array}$ & 109(90.1) & $12(9.9)$ & 0.71 & 0.60 & 0.29 & 1.22 & 0.16 \\
\hline & $\begin{array}{l}\text { Incomplete } \\
\text { secondary }\end{array}$ & $259(93.5)$ & $18(6.5)$ & $0.45^{\star \star}$ & 0.38 & 0.21 & 0.70 & 0.01 \\
\hline & $\begin{array}{l}\text { Complete } \\
\text { secondary }\end{array}$ & $47(85.5)$ & $8(14.5)$ & 1.09 & 1.30 & 0.56 & 3.03 & 0.55 \\
\hline & Higher & $256(86.5)$ & $40(13.5)$ & Ref & Ref & - & - & Ref \\
\hline
\end{tabular}




\begin{tabular}{|c|c|c|c|c|c|c|c|c|}
\hline \multirow{2}{*}{$\begin{array}{l}\text { Child lives } \\
\text { with }\end{array}$} & Mother & 2931(83.2) & $593(16.8)$ & - & - & - & - & $\ldots$ \\
\hline & Elsewhere & $3(100.0)$ & $0(0.0)$ & - & - & - & - & - \\
\hline \multirow{2}{*}{$\begin{array}{l}\text { Caesarean } \\
\text { section }\end{array}$} & No & 2915(83.2) & $589(16.8)$ & 0.96 & - & - & - & - \\
\hline & Yes & 19(82.6) & $4(17.4)$ & Ref & - & - & - & - \\
\hline \multirow[t]{4}{*}{ Region } & Afar & 733 (81.1) & $\begin{array}{l}171 \\
(18.9)\end{array}$ & $1.60 * \star$ & 1.03 & 0.62 & 1.72 & 0.90 \\
\hline & Somali & 1066(83.4) & $212(16.6)$ & $1.37^{\star \star}$ & 0.97 & 0.59 & 1.60 & 0.90 \\
\hline & Benishangul & 634(82.2) & 137(17.8) & $1.48 * \star$ & 1.34 & 0.86 & 2.09 & 0.20 \\
\hline & Gambela & $501(87.3)$ & 73(12.7) & Ref & Ref & - & - & Ref \\
\hline \multirow{7}{*}{$\begin{array}{l}\text { Maternal } \\
\text { age }\end{array}$} & 15-19 & 141(96.6) & $5(3.4)$ & $0.05^{\star}$ & - & - & - & - \\
\hline & $20-24]$ & $745(92.5)$ & $60(7.5)$ & $0.12^{\star}$ & - & - & - & - \\
\hline & $25-29$ & $923(86.7)$ & $142(13.3)$ & $0.23^{\star}$ & - & - & - & - \\
\hline & $30-34$ & $593(79.1)$ & 157(20.9) & $0.40 *$ & - & - & - & - \\
\hline & $35-39$ & $376(72.4)$ & $143(27.6)$ & $0.58 * *$ & - & - & - & - \\
\hline & $40-44$ & $118(65.9 \%)$ & $61(34.1)$ & 0.79 & - & - & - & - \\
\hline & $45-49$ & $38(60.3)$ & $25(39.7)$ & Ref & - & - & - & - \\
\hline
\end{tabular}

NB: ${ }^{*}=p<0.001, * *=p<0.05, * * *=p<=0.20$

Table5: The association of under-five daughters mortality and potential determinates in the pastoralist communities, Ethiopia $(n=3527)$ 


\begin{tabular}{|c|c|c|c|c|c|c|c|c|}
\hline \multirow[t]{2}{*}{ Variable } & \multirow[t]{2}{*}{ Categories } & \multicolumn{2}{|c|}{ Childhood mortality } & \multicolumn{2}{|l|}{ OR } & \multicolumn{2}{|l|}{$95 \% \mathrm{Cl}$} & \multirow{2}{*}{$\begin{array}{l}\mathrm{P}- \\
\text { value }\end{array}$} \\
\hline & & Alive & Died & COR & AOR & Lower & Upper & \\
\hline \multirow[t]{5}{*}{ Wealth index } & Poorest & 1848(83.1) & $376(16.9)$ & $2.44^{\star}$ & 1.890 & 1.24 & 2.89 & 0.01 \\
\hline & Poorer & $322(82.8)$ & $67(17.2)$ & $2.50 *$ & 1.94 & 1.19 & 3.16 & 0.01 \\
\hline & Medium & $224(86.8)$ & $34(13.2)$ & $1.82^{\star \star}$ & 1.38 & 0.80 & 2.39 & 0.25 \\
\hline & Richer & $218(86.2)$ & $35(13.8)$ & $1.93^{\star \star}$ & 1.62 & 0.95 & 2.76 & 0.08 \\
\hline & Richest & $372(92.3)$ & $31(7.7)$ & Ref & Ref & - & - & Ref \\
\hline \multirow[t]{2}{*}{ Residence } & Rural & $2516(83.6)$ & 492(16.4) & 1.80 & - & - & - & - \\
\hline & Urban & $468(90.2)$ & $51(9.8)$ & Ref & - & - & - & - \\
\hline \multirow[t]{2}{*}{ Smoking } & No & 2944(84.6) & $535(15.4)$ & `Ref & - & - & - & - \\
\hline & Yes & $40(83.3)$ & $8(16.7)$ & 1.10 & - & - & - & - \\
\hline \multirow[t]{6}{*}{ Religion } & Orthodox & 262(91.9) & $23(8.1)$ & Ref & Ref & - & - & Ref \\
\hline & Catholic & 13(81.2) & $3(18.8)$ & $2.63^{\star \star \star}$ & 3.48 & 0.88 & 13.99 & 0.08 \\
\hline & Protestant & $513(89.8)$ & $58(10.2)$ & 1.29 & 1.32 & 0.74 & 2.35 & 0.36 \\
\hline & Muslim & $2126(82.6)$ & $448(17.4)$ & $2.40 *$ & 2.70 & 1.64 & 4.44 & .001 \\
\hline & Traditional & $51(86.4)$ & $8(13.6)$ & $1.79 \star \star \star$ & 1.44 & 0.60 & 3.41 & 0.42 \\
\hline & Other & 19(86.4) & $3(13.6)$ & 1.80 & 1.88 & 0.49 & 7.25 & 0.36 \\
\hline \multirow{2}{*}{$\begin{array}{l}\text { Head of } \\
\text { household }\end{array}$} & Male & $2121(83.6)$ & $416(16.4)$ & Ref & Ref & - & - & Ref \\
\hline & Female & $863(87.2)$ & $127(12.8)$ & $0.75^{\star \star}$ & 0.74 & 0.60 & 0.93 & 0.01 \\
\hline \multirow[t]{3}{*}{$\begin{array}{l}\text { Was child } \\
\text { wanted }\end{array}$} & Wanted then & $\begin{array}{l}2672 \\
(84.3)\end{array}$ & $\begin{array}{l}496 \\
(15.7)\end{array}$ & Ref & Ref & - & - & Ref \\
\hline & Wanted latter & 234(89.3) & $28(10.7)$ & $0.65^{\star \star}$ & 0.76 & 0.50 & 1.17 & 0.21 \\
\hline & $\begin{array}{l}\text { Wanted no } \\
\text { more }\end{array}$ & 78(80.4) & $19(19.6)$ & 1.31 & 1.29 & 0.75 & 2.20 & 0.36 \\
\hline \multirow{2}{*}{$\begin{array}{l}\text { Marital } \\
\text { status }\end{array}$} & Married & $2966(84.6)$ & $539(15.4)$ & Ref & - & - & - & - \\
\hline & $\begin{array}{l}\text { Live with } \\
\text { partner }\end{array}$ & 18(81.8) & $4(18.2)$ & 1.2 & - & - & - & -- \\
\hline \multirow{2}{*}{$\begin{array}{l}\text { Khat } \\
\text { chewing }\end{array}$} & No & $2900(84.8)$ & $520(15.2)$ & Ref & Ref & - & - & Ref \\
\hline & Yes & $84(78.5)$ & $23(21.5)$ & $1.53^{\star \star \star}$ & 1.44 & 0.88 & 2.35 & 0.15 \\
\hline \multirow[t]{2}{*}{ Child sex } & Male & $1554(84.6)$ & $282(15.4)$ & Ref & - & - & - & - \\
\hline & Female & $1430(84.6)$ & $261(15.4)$ & 1.01 & - & - & - & - \\
\hline \multirow[t]{2}{*}{ Type of child } & Single birth & $2927(84.9)$ & $520(15.1)$ & Ref & Ref & - & - & Ref \\
\hline & & & Page $21 / 23$ & & & & & \\
\hline
\end{tabular}




\begin{tabular}{|c|c|c|c|c|c|c|c|c|}
\hline \multirow[t]{2}{*}{ birth } & $\begin{array}{l}\text { 1st of } \\
\text { multiple }\end{array}$ & $29(70.7)$ & 12(29.3) & $2.33^{\star \star}$ & 2.61 & 1.29 & 5.29 & 0.01 \\
\hline & $\begin{array}{l}\text { 2nd of } \\
\text { multiple }\end{array}$ & $28(71.8)$ & $11(28.2)$ & $2.21^{\star \star}$ & 2.29 & 1.11 & 4.76 & 0.03 \\
\hline \multirow{5}{*}{$\begin{array}{l}\text { Child age in } \\
\text { months }\end{array}$} & Birth to 12 & $668(87.4)$ & $96(12.6)$ & $0.61^{*}$ & 0.63 & 0.47 & 0.85 & 0.01 \\
\hline & 12 to 24 & $545(85.6)$ & $92(14.4)$ & $0.72^{\star \star}$ & 0.75 & 0.56 & 1.01 & 0.06 \\
\hline & 24 to 36 & $604(84.6)$ & $110(15.4)$ & $0.78^{* \star *}$ & 0.78 & 0.59 & 1.04 & 0.09 \\
\hline & 36 to 48 & $582(84.3)$ & 108(15.7) & $0.79 * \star \star *$ & 0.77 & 0.58 & 1.03 & 0.08 \\
\hline & 48 to 59 & $585(81.0)$ & 137(19.0) & Ref & Ref & - & - & Ref \\
\hline \multirow[t]{5}{*}{ Size of child } & Very large & 377 (81.6) & $85(18.4)$ & Ref & Ref & - & - & Ref \\
\hline & Large & 432 (83.9) & $83(16.1)$ & 0.85 & 0.81 & 0.57 & 1.14 & 0.22 \\
\hline & Average & $1286(86.2)$ & $206(13.8)$ & $0.71^{\star \star}$ & 0.68 & 0.51 & 0.90 & 0.01 \\
\hline & Small & $314(85.6)$ & $53(14.4)$ & $0.75^{\star \star \star}$ & 0.67 & 0.46 & 1.01 & .042 \\
\hline & Very small & 575 (83.2) & $\begin{array}{l}116 \\
(16.8)\end{array}$ & 0.90 & 0.79 & 0.57 & 1.10 & 0.16 \\
\hline \multirow[t]{2}{*}{$\begin{array}{l}\text { Place of } \\
\text { birth }\end{array}$} & Home & $\begin{array}{l}2269 \\
(83.7)\end{array}$ & $\begin{array}{l}442 \\
(16.3)\end{array}$ & $1.38^{\star \star}$ & 1.10 & 0.84 & 1.43 & 0.49 \\
\hline & Health facility & 715(87.6) & 101(12.4) & Ref & Ref & - & - & Ref \\
\hline \multirow{2}{*}{$\begin{array}{l}\text { Fast and } \\
\text { rapid } \\
\text { breathing }\end{array}$} & No & $\begin{array}{l}2828 \\
(84.7)\end{array}$ & $512(15.3)$ & Ref & - & - & - & - \\
\hline & Yes & 156 (83.4) & $31(16.6)$ & 1.10 & - & - & - & - \\
\hline \multirow{6}{*}{$\begin{array}{l}\text { Husband } \\
\text { education }\end{array}$} & No education & 1786(82.3) & $385(17.7)$ & $2.56^{\star}$ & 1.67 & 1.03 & 2.71 & 0.04 \\
\hline & $\begin{array}{l}\text { Incomplete } \\
\text { primary }\end{array}$ & $520(85.7)$ & $87(14.3)$ & $1.99 * \star$ & 1.46 & 0.87 & 2.44 & 0.15 \\
\hline & $\begin{array}{l}\text { Complete } \\
\text { primary }\end{array}$ & 105(86.8) & 16(13.2) & $1.81^{* \star \star}$ & 1.32 & 0.65 & 2.67 & 0.44 \\
\hline & $\begin{array}{l}\text { Incomplete } \\
\text { secondary }\end{array}$ & $250(90.3)$ & $27(9.7)$ & 1.28 & 1.09 & 0.60 & 1.98 & 0.78 \\
\hline & $\begin{array}{l}\text { Complete } \\
\text { secondary }\end{array}$ & $50(90.9)$ & $5(9.1)$ & 1.19 & 1.10 & 0.39 & 3.11 & 0.86 \\
\hline & Higher & 273(92.2) & $23(7.80)$ & Ref & Ref & - & - & Ref \\
\hline \multirow{4}{*}{$\begin{array}{l}\text { Maternal } \\
\text { education }\end{array}$} & No education & 2120(81.8) & 473(18.2) & - & - & - & - & - \\
\hline & Primary & 613(92.3) & $51(7.7)$ & - & - & - & - & - \\
\hline & Secondary & 175 (90.2) & $19(9.8)$ & - & - & - & - & - \\
\hline & Higher & 76 (100.0) & $0(0.0)$ & - & - & - & - & - \\
\hline
\end{tabular}




\begin{tabular}{|c|c|c|c|c|c|c|c|c|}
\hline \multirow[t]{2}{*}{$\begin{array}{l}\text { Child lives } \\
\text { with }\end{array}$} & Mother & $\begin{array}{l}2981 \\
(84.6)\end{array}$ & $543(15.4)$ & - & - & - & - & - \\
\hline & Elsewhere & $3(100.0)$ & $0(0.0)$ & - & - & - & - & - \\
\hline \multirow{2}{*}{$\begin{array}{l}\text { Caesarean } \\
\text { section }\end{array}$} & No & $2963(84.6)$ & $541(15.4)$ & 1.92 & - & - & - & - \\
\hline & Yes & 21(91.3) & $2(8.7)$ & Ref & - & - & - & - \\
\hline \multirow[t]{4}{*}{ Region } & Afar & 751(83.1) & 153(16.9) & $1.78^{*}$ & 0.73 & 0.43 & 1.25 & 0.25 \\
\hline & Somali & 1068(83.6) & $210(16.4)$ & $1.72^{\star}$ & 0.73 & 0.43 & 1.24 & 0.25 \\
\hline & Benishangul & $650(84.3)$ & 121(15.7) & $1.63^{\star}$ & 1.03 & 0.64 & 1.64 & 0.91 \\
\hline & Gambella & $515(89.7)$ & $59(10.3)$ & Ref & Ref & - & - & Ref \\
\hline \multirow{7}{*}{$\begin{array}{l}\text { Maternal } \\
\text { age }\end{array}$} & $15-19$ & 141(96.6) & $5(3.4)$ & $0.01 *$ & - & - & - & - \\
\hline & $20-24$ & $745(92.5)$ & $60(7.5)$ & $0.05^{\star}$ & - & - & - & - \\
\hline & $25-29$ & $923(86.7)$ & 142(13.3) & $0.13^{\star}$ & - & - & - & - \\
\hline & $30-34$ & $593(79.1)$ & 157(20.9) & $0.24^{\star}$ & - & - & - & - \\
\hline & $35-39$ & $376(72.4)$ & $143(27.6)$ & $0.37 *$ & - & - & - & - \\
\hline & $40-44$ & 118(65.9) & $61(34.1)$ & $0.68^{\star \star \star}$ & - & - & - & - \\
\hline & $45-49$ & $38(60.3)$ & 25(39.7) & Ref & - & - & - & - \\
\hline
\end{tabular}

NB: ${ }^{*}=p<0.001,{ }^{* *}=p<0.05,{ }^{* *}=P<=0.20$ 